\title{
Severe respiratory illness caused by a novel coronavirus, in a patient transferred to the United Kingdom from the Middle East, September 2012
}

\author{
A Bermingham1, M A Chand (meera.chand@hpa.org.uk) ${ }^{1}$, C S Brown ${ }^{1,2}$, E Aarons ${ }^{3}, \mathrm{C}$ Tong $^{3}$, C Langrish ${ }^{3}, \mathrm{~K} \mathrm{Hoschler}^{1}$, K Brown , $^{1}$ \\ M Galiano ${ }^{1}$, R Myers ${ }^{1}$, R G Pebody ${ }^{1}$, H K Green ${ }^{1}$, N L Boddington ${ }^{1}$, R Gopal $^{1}$, N Price ${ }^{3}$, W Newsholme ${ }^{3}$, C Drosten ${ }^{4}$, R A Fouchier \\ M Zambon ${ }^{1}$ \\ 1. Health Protection Agency (HPA), London, United Kingdom \\ 2. Centre for Clinical Infection and Diagnostics Research, King's College London, London, England \\ 3. Guy's and St Thomas' NHS Foundation Trust and King's Health Partners, London, United Kingdom \\ 4. Institute of Virology, University of Bonn Medical Centre, Bonn, Germany \\ 5. Department of Virology, Erasmus Medical Centre, Rotterdam, the Netherlands
}

Citation style for this article:

Bermingham A, Chand MA, Brown CS, Aarons E, Tong C, Langrish C, Hoschler K, Brown K, Galiano M, Myers R, Pebody RG, Green HK, Boddington NL, Gopal R, Price N, Newsholme W, Drosten C, Fouchier RA, Zambon M. Severe respiratory illness caused by a novel coronavirus, in a patient transferred to the United Kingdom from the Middle East, September 2012. Euro Surveill. 2012;17(40):pii=20290. Available online: http://www.eurosurveillance.org/ViewArticle.aspx?Articleld=20290

Article submitted on 27 September 2012 / published on 4 October 2012

Coronaviruses have the potential to cause severe transmissible human disease, as demonstrated by the severe acute respiratory syndrome (SARS) outbreak of 2003. We describe here the clinical and virological features of a novel coronavirus infection causing severe respiratory illness in a patient transferred to London, United Kingdom, from the Gulf region of the Middle East.

\section{Introduction}

Coronaviruses are recognised causes of mild respiratory tract infections in humans, first identified in the 1960 s [1]. These large RNA viruses affect a wide range of animals including domestic and companion animals and bats [2]. Limited surveillance data show that bats host the greatest diversity of coronaviruses, varying by region and species [3], suggesting that they may be the natural reservoir.

The severe acute respiratory syndrome (SARS) outbreak of 2003 - affecting over 8,000 people across three continents with a case fatality ratio of about $10 \%$ [4] - indicates the potential of an animal coronavirus to jump species and transmit from person to person causing severe illness. This experience has raised awareness of the potential threat from zoonotic coronaviral infections and the need to adopt strict infection control measures when such cases are found, especially in healthcare settings. We describe here the clinical features and diagnostic detection of a novel coronavirus infection in a severely ill adult transferred to London, United Kingdom, from the Gulf region of the Middle East for medical care.

\section{Case history}

On 14 September 2012, the United Kingdom Health Protection Agency (HPA) Imported Fever Service was notified of a case of unexplained severe respiratory illness in a London intensive care unit. The patient had recently transferred from Qatar and had a history of travel to Saudi Arabia.

He was a previously well 49 year-old man who developed a mild undiagnosed respiratory illness while visiting Saudi Arabia during August 2012, which fully resolved. He subsequently presented to a physician in Qatar on 3 September, with cough, myalgia and arthralgia, and was prescribed oral antibiotics. Five days later, he was admitted to a Qatari hospital with fever $\left(38.4^{\circ} \mathrm{C}\right)$ and hypoxia, with oxygen saturation of $91 \%$ on room air. A chest X-ray showed bilateral lower zone consolidation. He was treated with ceftriaxone, azithromycin and oseltamivir. After 48 hours, he required intubation and ventilation and was transferred by air ambulance to London. During transfer, he was clinically unstable, requiring manual ventilation.

On admission to intensive care in London, he remained severely hypoxic, achieving an arterial $\mathrm{PaO}_{2}$ of $6.5 \mathrm{kPA}$ (normal range: $11-13 \mathrm{kPA}$ ) on $100 \%$ oxygen with optimised pressure ventilation, and required low-dose norepinephrine to maintain blood pressure. His white blood cell count was $9.1 \times 10^{9} / \mathrm{L}$ (normal range: 4-11 $\mathrm{x}$ $10^{9} / \mathrm{L}$ ), C-reactive protein $350 \mathrm{mg} / \mathrm{L}$ (normal range: $0-10$ $\mathrm{mg} / \mathrm{L}$ ) and creatinine $353 \mu \mathrm{mol} / \mathrm{L}$ (normal range: 53-97 $\mu \mathrm{mol} / \mathrm{L})$, with normal liver function and coagulation. He was treated with corticosteroids and broad-spectrum antibiotics, initially meropenem, clarithromycin and teicoplanin. Colistin and liposomal amphotericin B were subsequently added.

His condition deteriorated between 11 and 20 September, with progressive hypoxia. His C-reactive protein level peaked at $440 \mathrm{mg} / \mathrm{L}$ and procalcitonin at $68 \mathrm{ng} / \mathrm{ml}$ (normal level: $<0.5 \mathrm{ng} / \mathrm{ml}$ ). His renal function worsened and haemofiltration was initiated on 14 
Microbiological investigations performed on London patient with novel coronavirus infection, September 2012

\begin{tabular}{|c|c|c|c|c|c|c|c|c|c|c|c|c|c|c|c|c|c|c|}
\hline \multirow{2}{*}{ Source } & \multirow{2}{*}{ Sample } & \multicolumn{17}{|c|}{ Date of investigation (September 2012) } \\
\hline & & 9 & 10 & 11 & 12 & 13 & 14 & 15 & 16 & 17 & 18 & 19 & 20 & 21 & 22 & 23 & 24 & 25 \\
\hline Qatar & Broncho-alveolar lavage & & & & & & & & & & & & & & & & & \\
\hline \multirow{7}{*}{$\begin{array}{l}\text { London: } \\
\text { ICU }\end{array}$} & Combined nose and throat swab & & & & & & & & & & & & & & & & & \\
\hline & Local bacterial/viral testing $^{\text {a }}$ & & & & & & & & & & & & & & & & & \\
\hline & $\begin{array}{l}\text { Imported fever panel } \\
\text { (blood/serum/urine/throat swab) }^{\mathrm{b}}\end{array}$ & & & & & & & & & & & & & & & & & \\
\hline & Sputum & & & & & & & & & & & & & & & & & \\
\hline & Nose swab & & & & & & & & & & & & & & & & & \\
\hline & Throat swab & & & & & & & & & & & & & & & & & \\
\hline & Tracheal aspirate & & & & & & & & & & & & & & & & & \\
\hline \multirow{4}{*}{$\begin{array}{l}\text { London: } \\
\text { specialist } \\
\text { ICU }\end{array}$} & Broncho-alveolar lavage $^{c}$ & & & & & & & & & & & & & & & & & \\
\hline & Cerebrospinal fluid & & & & & & & & & & & & & & & & & \\
\hline & Blood (EDTA/serum) & & & & & & & & & & & & & & & & & \\
\hline & Stool & & & & & & & & & & & & & & & & & \\
\hline
\end{tabular}

EDTA: ethylenediaminetetraacetic acid; ICU: intensive care unit; PCR: polymerase chain reaction.

Red $=$ coronavirus detected (pan-coronavirus assay and real-time PCR assay for UpE and ORF1b (specific for novel coronavirus)

Green $=$ no pathogens detected, including testing by pan-coronavirus assay

Blue = negative for all pathogens (not tested by pan-coronavirus assay)

a Included multiple blood and sputum cultures; urinalysis; atypical pneumonia screen; blood-borne virus screen; Epstein-Barr virus, cytomegalovirus, and varicella zoster virus; respiratory virus screen; mycobacterial respiratory screen; and tracheostomy site culture.

b Included dengue virus; West Nile virus; chikungunya virus; hantavirus; Sindbis virus; Rift Valley fever virus; sandfly viruses; Rickettsiae; Coxiella burnettii; Burkholderia mallei and B. pseudomallei.

Negative for respiratory bacterial culture and mycobacterial stain and respiratory Influenza A/B, parainfluenza 1-4, RSV A/B, human metapneumovirus, enterovirus, rhinovirus, adenovirus, human bocavirus, and the human coronaviruses (NL63, 229E, OC43, HKU1).

September. He was transferred to a specialist intensive care unit and on 20 September (day 17 of illness), extracorporeal membrane oxygenation (ECMO) was started. As of 2 October, he remains stable but fully dependent on ECMO after 13 days (day 30 of illness).

\section{Diagnostic approach}

Microbiological diagnostics in Qatar and London were used to look initially for common viral and bacterial causes of severe respiratory illness and subsequently for pathogens endemic in the Middle East (Table 1). By mid-September, the syndrome was considered most compatible with viral pneumonia. Upper and lower respiratory tract samples were sent to the HPA Respiratory Virus Unit for extended influenza testing; all were negative. On 20 September, a ProMED report described a novel human coronavirus recovered from an adult male Saudi Arabian who died in June 2012 following acute respiratory illness, pneumonia and renal failure [5]. The Erasmus Medical Center (the Netherlands) had sequenced the virus and identified it as a previously undescribed coronavirus, related to known bat coronaviruses. Given that the patient described in our report had travelled to Saudi Arabia, HPA, in consultation with local clinicians, decided to investigate samples from the patient for the presence of the novel coronavirus.

\section{Detection of a novel coronavirus}

We used real-time PCR on upper (nose and throat swabs) and lower respiratory tract samples (sputum and tracheal aspirates) to test for a range of coronaviruses: OC43, 229E, NL63 and SARS-CoV. We also used 
TABLE 2

Real-time PCR results of coronavirus samples, September 2012

\begin{tabular}{|c|c|c|c|c|}
\hline \multirow{2}{*}{ Sample/isolate } & \multicolumn{2}{|c|}{ E Gene } & \multicolumn{2}{|c|}{ ORF 1b Gene } \\
\hline & Rotorgene (Ct) & $\mathrm{ABI}$ Taqman $(\mathrm{Ct})$ & Rotorgene (Ct) & $\mathrm{ABI}$ Taqman $(\mathrm{Ct})$ \\
\hline \multicolumn{5}{|c|}{ Novel coronavirus isolated in the Netherlands (patient from Saudi Arabia) reported to ProMED } \\
\hline $\begin{array}{l}\text { Cultured virus (approximate } \\
\text { titre } 10^{6} / \mathrm{ml} \text { ) }\end{array}$ & 18.9 & 17.5 & 22.7 & 21.9 \\
\hline \multicolumn{5}{|c|}{ Samples from confirmed case in London } \\
\hline $\begin{array}{l}\text { Combined nose } \\
\text { and throat swab } \\
13 / 9 / 2012\end{array}$ & 30.5 & 28.8 & 35.6 & 35.4 \\
\hline $\begin{array}{l}\text { Sputum } \\
17 / 12 / 2012\end{array}$ & 28.3 & 26.6 & 32.8 & 31.7 \\
\hline $\begin{array}{l}\text { Deep tracheal } \\
\text { aspirate } \\
19 / 12 / 2012\end{array}$ & 26.2 & 24.9 & 31.4 & 30.0 \\
\hline
\end{tabular}

Ct: cycle threshold; PCR: polymerase chain reaction.

Results of specific real-time PCR assays [10] directed towards the upstream E gene (UpE) and the ORF 1b region of the new coronavirus tested against cultured virus from the patient who died in Saudi Arabia, and clinical material from the confirmed case of novel coronavirus in London.

a block-based pan-coronavirus PCR with degenerate primers targeted to the conserved RNA-dependent RNA polymerase ( $\mathrm{RdRp} \mathrm{Pol}$ ) gene that detects all coronaviruses known to infect humans and a range of animal coronaviruses [6]. The pan-coronavirus assay yielded a band of the correct size in lower respiratory tract samples, but the assays for $\mathrm{OC}_{43}, 229 \mathrm{E}, \mathrm{NL} 63$ and SARScoronaviruses were negative. Sanger sequencing of the pan-coronavirus PCR product (a 251 base pair fragment encompassing nucleotides 104-354 of the NSP12 gene) yielded a sequence that on BLAST analysis gave genetic identity of $81 \%$ to bat coronavirus/133/2005 (GenBank accession number DQ648794.1) and 75\% identity to porcine haemagglutinating encephalomyelitis virus strain VW572 (GenBank accession number DQ011855.1) The sequence identified is available on the HPA website [7]. In response to this identification, a new set of real-time RT PCR assays were developed [8]. The results of these assays tested on novel coronavirus tissue culture material and clinical samples from this confirmed case are shown in Table 2.

On the basis of the sequence obtained, a maximum likelihood tree (Figure) showed that the virus belongs to the genus Betacoronavirus, with closest relationships to bat coronaviruses $\mathrm{HKU}_{4}$ and $\mathrm{HKU}_{5}$. Viruses that share more than $90 \%$ sequence identity in the conserved replicase domain are considered to belong to the same species by the International Committee on Taxonomy of Viruses (ICTV). Our sequence comparisons suggested that the virus nucleic acid fragment identified is derived from a novel coronavirus that is distinct from all coronaviruses described to date.
A total of 13 close contacts of the index case were identified who had developed mild self-limiting respiratory illnesses since exposure to the case [8]. Ten of these have had nose and throat swabs tested by pancoronavirus assay and the novel coronavirus was not detected.

\section{Discussion}

Ascribing viral taxonomy on the basis of a small segment of sequence representing less than $1 \%$ of a viral genome is highly presumptive. However, the replicase genes are extremely conserved within coronaviruses, and the gene targeted by the pan-coronavirus assay is highly correlated with taxonomic classification based on the whole genome [9], confirming the choice of assay and the validity of the phylogeny (Figure). Final allocation of taxonomy and nearest neighbour relatedness will require more extensive sequence obtained either through genomic analysis of virus isolates cultured from the available clinical material, or more extensive partial genome sequence derived directly from clinical material if virus isolation is not possible.

While most coronaviral infections of humans cause mild illness, zoonotic transmission of animal coronaviruses such as SARS-CoV can cause severe illness and death. Preliminary data sharing (Ron Fouchier, personal communication, 23 September 2012) indicates 99.5\% identity over the region of the replicase compared with the virus isolated from the patient in Saudi Arabia and described in ProMED. This is confirmed by the publication of the whole genome sequence (GenBank accession number JX869059.1). On the basis of the clinical and virological features, we believe that the fragment 
Phylogenetic relationships of partial sequences from the polymerase gene (nsp12) of the coronavirus sequence obtained at the Health Protection Agency, together with representative coronaviruses from different groups

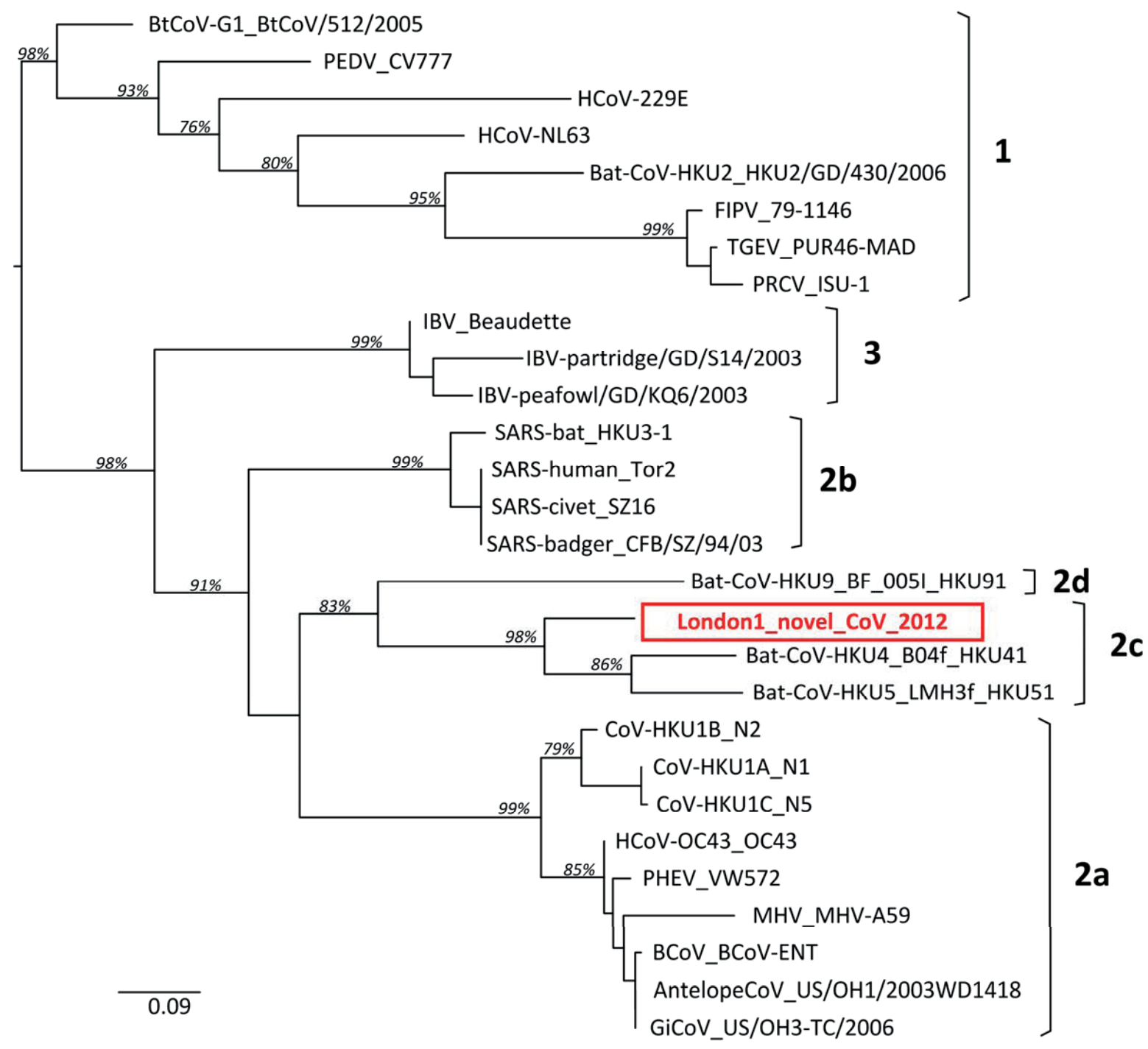

The sequence obtained at the Health Protection Agency has been tentatively named as London1_novel CoV 2012. The phylogenetic tree was constructed with fastTree software, using the maximum-likelihood method with general time-reversible model of nucleotide substitution. Bootstrap values were obtained with 1,000 replicates. Coronavirus groups are shown on the right hand side of the tree, with 1,2 and 3 corresponding to Alpha, Beta and Gammacoronaviruses respectively.

of coronaviral sequence we have recovered represents a novel human coronavirus causing a severe respiratory illness.

The rapid development of sensitive and specific molecular diagnostics for new organisms is facilitated by sharing information and data between laboratories with different capabilities or reagents. The initial molecular approaches used in this case were part of a broad screening approach based on experience gained during the response to SARS. The development of specific diagnostics for the novel coronavirus will improve sensitivity and enable rapid exclusion or identification of potential clinical cases.
The origin for this novel virus is unknown. Epidemiological human and animal investigations in the region of origin are required to distinguish between an animal reservoir that either directly or indirectly transmits the virus occasionally to humans, and a previously unrecognised endemic infection of humans that causes severe outcomes in a few of those infected. Distinguishing between these possibilities will require wider application of more specific and sensitive molecular assays for coronaviruses, and greater awareness of the possible presence of coronaviruses in human acute severe respiratory illness. Extensive serological testing of potentially exposed human populations and contacts will be a key indicator of the extent of disease due to novel coronaviruses. 


\section{References}

1. Tyrrell DA, Bynoe ML. Cultivation of a novel type of commoncold virus in organ cultures. Br Med J. 1965;1(5448):1467-70.

2. Shi Z, Hu Z. A review of studies on animal reservoirs of the SARS coronavirus. Virus Res. 2008;133(1):74-87.

3. Anderson LJ, Tong S. Update on SARS research and other possibly zoonotic coronaviruses. Int J Antimicrob Agents. 2010;36 Suppl 1:S21-5.

4. World Health Organization (WHO). Summary table of SARS cases by country, 1 November 2002 - 7 August 2003. Geneva: WHO; 15 Aug 2003. Available from: http://www.who.int/csr/ sars/country/2003_08_15/en/index.html

5. ProMED mail. Novel coronavirus - Saudi Arabia: human isolate. Archive Number: 20120920.1302733. Available from: http:// www.promedmail.org/?p=2400:1000

6. Bermingham A, Heinen P, Iturriza-Gómara M, Gray J, Appleton $\mathrm{H}$, Zambon MC. Laboratory diagnosis of SARS. Philos Trans R Soc Lond B Biol Sci. 2004;359(1447):1083-9.

7. Health Protection Agency (HPA). Partial genetic sequence information for scientists about the novel coronavirus 2012. London: HPA. [Accessed 2 Oct 2012]. Available from: http://www.hpa.org.uk/Topics/ InfectiousDiseases/InfectionsAZ/NovelCoronavirus2012/ respPartialgeneticsequenceofnovelcoronavirus/

8. Pebody RG, Chand MA, Thomas HL, Green HK, Boddington NL, Carvalho C, et al. The United Kingdom public health response to an imported laboratory confirmed case of a novel coronavirus in September 2012. Euro Surveill. 2012;17(40):pii=20292. Available from: http://www. eurosurveillance.org/ViewArticle.aspx?Articleld=20292

9. Drexler JF, Gloza-Rausch F, Glende J, Corman VM, Muth D, Goettsche M, et al. Genomic characterization of severe acute respiratory syndrome-related coronavirus in European bats and classification of coronaviruses based on partial RNA-dependent RNA polymerase gene sequences J Virol. 2010;84(21):11336-49.

10. Corman VM, Eckerle I, Bleicker T, Zaki A, Landt O, EschbachBludau M, et al. Detection of a novel human coronavirus by real-time reverse-transcription polymerase chain reaction. Euro Surveill. 2012;17(39):pii=20285. Available online: http:// www.eurosurveillance.org/ViewArticle.aspx?Articleld=20285 